IZA DP No. 7279

Top-Down vs. Bottom-Up:

The Long-Term Impact of Government Ideology and Personal Experience on Values

Nicolas R. Ziebarth

Gert G. Wagner

March 2013 


\title{
Top-Down vs. Bottom-Up: The Long-Term Impact of Government Ideology and Personal Experience on Values
}

\author{
Nicolas R. Ziebarth \\ Cornell University, \\ DIW Berlin and IZA \\ Gert G. Wagner \\ DIW Berlin, TU Berlin \\ and MPI for Human Development
}

Discussion Paper No. 7279

March 2013

\author{
IZA \\ P.O. Box 7240 \\ 53072 Bonn \\ Germany \\ Phone: +49-228-3894-0 \\ Fax: +49-228-3894-180 \\ E-mail: iza@iza.org
}

Any opinions expressed here are those of the author(s) and not those of IZA. Research published in this series may include views on policy, but the institute itself takes no institutional policy positions. The IZA research network is committed to the IZA Guiding Principles of Research Integrity.

The Institute for the Study of Labor (IZA) in Bonn is a local and virtual international research center and a place of communication between science, politics and business. IZA is an independent nonprofit organization supported by Deutsche Post Foundation. The center is associated with the University of Bonn and offers a stimulating research environment through its international network, workshops and conferences, data service, project support, research visits and doctoral program. IZA engages in (i) original and internationally competitive research in all fields of labor economics, (ii) development of policy concepts, and (iii) dissemination of research results and concepts to the interested public.

IZA Discussion Papers often represent preliminary work and are circulated to encourage discussion. Citation of such a paper should account for its provisional character. A revised version may be available directly from the author. 


\section{ABSTRACT \\ Top-Down vs. Bottom-Up: The Long-Term Impact of Government Ideology and Personal Experience on Values*}

This paper studies the long-term impact of societal socialization on values using the example of doping behavior in sports. We apply the German Reunification Approach to the microcosm of Berlin and exploit its 40-year long division into a capitalist and a communist sector. We deliberately chose attitudes toward doping to test the impact of ideology on values since (i) post-1989 disappointed economic hopes did not confound doping attitudes, and because of (ii) the systematic GDR state doping activities that became public in reunified Germany in the 1990s. Our findings demonstrate that even after half the time the division lasted, e.g. 20 years after the reunification, differences in convictions continue to persist. Personal extramural sports experience and age are equally strong predictors of individual attitudes and beliefs, especially in interaction with ideological socialization.

JEL Classification: I18, K40, L83, N34, Z13

Keywords: communism, values, performance-enhancement drugs, Berlin, natural experiment

Corresponding author:

Nicolas R. Ziebarth

Cornell University

Policy Analysis and Management (PAM)

106 Martha van Rensselaer Hall

Ithaca, NY 14853

USA

E-mail: nrz2@cornell.edu

\footnotetext{
* We thank Damon Clark, Dan Lichter, Douglas Wolf and participants at the Fall Meeting of the Association of Public Policy Analysis and Management (APPAM) as well as the 2012 Cornell Population Center Encore Conference. A special thank goes to Adam Lederer for co-editing this paper. We also thank Aline Passlack for excellent research assistance and take responsibility for all remaining errors in and shortcomings of the article. Generous support from the Deutsche Forschungsgemeinschaft (DFG; "German Science Foundation", WA 547/5-1) and the Open Research Area in Europe for the Social Sciences (ORA-10-36) is gratefully acknowledged.
} 


\section{Introduction}

A fruitful and influential strand of the economic literature analyzes the interdependencies between culture and attitudes, institutions and economic growth. Substantial cross-country differences in corruption, democratization, and societal preferences are found to be correlated with economic prospects, giving rise to a plentitude of hypothesis of the underlying relationships. However, due to a lack of clear exogenous variation of the variable of interest as well as the potentially confounding impact of cross-country unobservables, the empirical testing of such hypotheses remains challenging.

One empirical approach is to rely on survey data from different countries, group the countries according to their political and religious history, then derive conclusions from differences in respondents' values expressed (cf. Pryor, 2007; Gerlach et. al. 2008; Aghion et al. 2010; Grosjean and Senik, 2011). More refined approaches exploit historical peculiarities to infer causality. For example, Acemoglu et al. (2001) use historical differences in mortality rates in European countries as an instrument for the quality of institutions. They find substantial effects on economic growth. Becker et al. (2011) use the former "Habsburg border" in Europe to identify a positive long-running impact of the Habsburg Empire on current trust levels and corruption. Eugster et al. (2011) use language borders in Switzerland to estimate the impact of culture on attitudes toward the welfare state. And the effect of culture on attitudes toward redistribution is analyzed by Luttmer and Singhal (2011), who exploit variation in distributional preferences in immigrants' country of birth. A very similar identification strategy is applied by Algan and Cahuc (2010), who find a positive impact of trust on economic growth.

The fall of the Soviet Union and the fall of the "iron curtain" in Europe have been established as a natural experimental and identification strategy to derive the impact of communism on a battery of outcomes (cf. Shiller et al. 1991; Blanchflower and Freeman, 1997). A substrand of the literature focuses on the division of Germany into East and West Germany in 1949 and its subsequent 1990 reunification (cf. Burszty and Cantoni, 2012). This approach excludes that systematic cross-country differences in unobservables confound the empirical estimates. It is argued that the geographic division of Germany after World War II (WWII) by 
the Soviet and Western Allies was a random event. Indeed, historical facts support this assumption as the erection of the Berlin Wall on August 13, 1961 was as unexpected as the peaceful fall of the Wall on November 9, 1989.

Thus, the main underlying identification assumption of using the German reunification as a natural experiment aims at a random division of Germany with otherwise two identical populations. The treatment group was exposed to communism, while the control group experienced a Western capitalist democracy for almost 40 years. Given the lack of data, the common and accepted methodological approach is to use post-reunification data and to compare East with West Germany (Frijters et al., 2004; Frijters et al., 2005; Fuchs-Schündeln and Schündeln, 2005; Alesina and Fuchs-Schündeln, 2007; Fuchs-Schündeln, 2008; Rainer and Siedler, 2009; Brosig-Koch et al. 2011; Burchardi and Hassan, 2013). However, there are at least three potential concerns with this approach:

a.) It is thinkable that due to state-differences in century old cultures, geographic as well as infrastructural conditions, East Germans were and are not comparable to West Germans (cf. Wolf, 2009).

b.) After WWII as well as before the erection of the Berlin Wall, millions of Germans resettled and migrated between East and West Germany. For example, after WWII Germany lost $25 \%$ of its territory. Approximately 12 million Germans who lived in (former) eastern territories that became Poland and Russia were expelled and sorted into East and West Germany before 1950. In addition, between 1950 and 1961-before the erection of the Berlin Wall-3.6 million residents of the German Democratic Republic (GDR), i.e. East Germany, migrated to the Federal Republic of Germany (FRG), i.e. West Germany.

c.) Most studies have to rely on data that were not collected immediately after the fall of the Wall, but 5 to 10 years after the reunification. To the extent that only current residency can be used to establish treatment status, such an approach ignores the 
potentially confounding impact of 3.4 million East Germans who migrated to West Germany after the fall of the Wall in 1989.

In addition, and perhaps even more importantly, in the emotional events of the reunification Western politicians raised high hopes about a prosperous future among former residents of the GDR. These hopes were, however, largely unfulfilled after reunificationmainly because of the weak East German labor market performance with unemployment rates that were, and still are, persistently twice as high as in West Germany (cf. Sinn, 2002; Uhlig, 2006; Burda, 2006). Disappointed economic hopes may act as a confounding factor when assessing the impact of communism on economic outcomes variables.

This paper makes three main contributions: First, it tests and improves upon the standard methodology in the literature that compares East with West German residents to assess the impact of communism. We exploit the city of Berlin as a microcosm of Germany's division and reunification. Like Germany as a whole, Berlin was divided into four sectors and had a communist and capitalist part. We argue that East Berliners and West Berliners are more similar and comparable than East Germans and West Germans in general. Most importantly, during the 20 years following the peaceful reunification, Berliners were exposed to the same state government, institutions, and local labor market conditions. Likewise, East-West migration within Berlin was much less pronounced that the drastic East-West German migration flows pre and post the erection of the Wall.

For that purpose, we conducted a telephone survey among current residents of Berlin and asked the respondents about their attitudes toward doping in sports. It is well known that systematic coaching of adolescents in Elite Level Sport Centers, as well as the experiencing with performance-enhancing drugs, were integral part of the GDR regime (see Section 2.1 for more details). We deliberately chose attitudes toward doping to test the impact of government ideology on values since (i) systematic doping was integral part of the GDR regime, (ii) these activities became public and were discussed in the common German media in the 1990s, and (iii) disappointment about the economic development is very unlikely to serve as a confounder in this setting. 
Exploiting this unique setting, we test whether decades-long exposure to an ideological political system manifests itself in personal values that can be detected two decades after the end of the regime. Respondents who lived in East Berlin before the fall of the BerlinWall act as treatment group and respondents who lived in the same city, but in West Berlin, as controls. Moreover, we can identify people who moved from East to West Berlin after the reunification and vice versa, then assess whether these migration flows bias our estimates. Thus, overall, our Berlin approach intends to minimize potential confounding factors that critics mention in the standard East-West German comparison approach. We show that that focusing on current instead of pre-1989 residency yields surprisingly robust results, although coefficients decrease in magnitude and are less precisely estimated. Thus our findings confirm the methodological validity of exploiting the German division as a natural experiment.

A second main contribution of this paper is to test the relative importance of personal involvement in terms of active decision-making vs. passive exposure to a regime's ideology. The political economy literature only implicitly discusses the relative importance of macroeconomic environmental conditions such as culture, institutions, or economic conditions as compared to microeconomic individual conditions such as family ties or individual values (cf. Alesina and Giuliano, 2011; Tabellini, 2008; Malmendier and Nagel, 2011). To compare the relative importance of macro conditions to micro conditions, we ask the respondents whether they had been athletes earlier in their life. Then we contrast the predictive power of state socialization with the predictive power of personal past involvement in extramural competitive sports. As such, we directly compare the importance of active individual-level involvement to passive global-level exposure with respect to their impacts on values and attitudes.

Even after a two decade long common exposure to political, institutional, and local labor market conditions, we find that the four decade long division of Germany still affects values significantly. Past, but active, individual sport involvement and age are equally strong predictors of convictions. They unfold their predictive power both in levels and in interaction with government ideology. 
Finally, this paper adds to the health behavior literature (cf. Carpenter, 2005; Cawley and Ruhm, 2011; Crost and Rees, 2013; Lillard et al. 2013; Rashad and Kaestner, 2004) and the economics literature on doping. The latter is relatively sparse and mainly focuses on the (game) theoretical modeling of doping behavior in contests (cf. Bird and Wagner, 1997; Szymanski, 2003). We provide evidence how government ideology shapes individual attitudes toward health behavior. Analyzing the changing health-related lifestyle patterns of transition economies helps to better understand future health trends in these economies.

The next section briefly describes the historical events around the division and reunification of Germany and summarizes evidence on systematic doping activities initiated by the former GDR regime. After that, Section 3 describes the data, while Section 4 presents and discusses our findings. Section 5 concludes.

\section{Background}

In the following, first, we briefly summarize the historical events around the division and reunification of Germany. This (i) helps to understand why and how the German reunification is used as a natural experiment in the economics literature, and (ii) illustrates the potential pitfalls associated with this approach due to the massive migration flows during and after WWII as well as before the erection and after the fall of the Berlin Wall.

Second, we summarize the existing evidence of systematic doping in the former GDR.

\subsection{Division and Reunification of Germany}

After WWII, Germany's boundaries changed substantially from its pre-war borders. At the Potsdam Conference in summer 1945, the allies divided Germany into four military occupation zones: American, British, French, and Soviet zones. The division was based on the idea of allocating territory proportional to the size of the nations' army and according to military considerations (Mee, 1975).

[Insert Figure 1 about here] 
Figure 1 illustrates that Eastern territories such as East Prussia and large parts of Pomerania became parts of Poland and Russia. These territories accounted for almost 25 percent of the total pre-war German territory and included 15 percent of Germany's total population (Statistisches Bundesamt, 1953). About 12 million German citizens and ethnically German people living east of the Oder River were expelled or fled from these (former) eastern German territories toward the end of the war and in the years following the Potsdam Conference ("Heimatvertriebene"). By 1950, West Germany had taken in 8 million of these Heimatvertriebene from former eastern German-now Polish and Russian-territory. This boosted West Germany's (which became the "Federal Republic of Germany (FRG)" in 1949), population by 17 percent. The remaining 4 million expellees resettled in East Germany (which became the "German Democratic Republic (GDR)" in 1949) (Beer, 2011, Bauer et al., 2013). These post-WWII, pre-1950, migration flows are important in this context since the natural experiment approach assumes that the populations in East and West Germany were comparable and had identical characteristics. However, it is likely that the 12 million Heimatvertriebene sorted into the Soviet and Western Allies zones based on observable and unobservable characteristics.

In 1949, the capitalist and democratic Federal Republic of Germany (FRG) was founded, comprising of the French, British, and American military occupation zones. As can be inferred from Figure $2 \mathrm{a}$ and $2 \mathrm{~b}$, in the Soviet zone the German Democratic Republic (GDR)-a totalitarian Stalin-oriented communist state-was forged in 1949. Between 1950 and 1961, about 3.6 million refugees migrated from the GDR to the FRG (Bethlehem, 1999). After the Heimatvertriebene, this represents the second large migration flow before the erection of the Wall.

\section{[Insert Figure $2 \mathrm{a}$ and $\mathbf{2 b}$ about here]}

To stop the mass exodus, on August 13, 1961, the communist GDR regime started erecting a 155 kilometers (96 miles) long cement and 3.6 meter (12 feet) high "Berlin Wall" around West Berlin (see Figure 3). As Figure 2b shows, West Berlin was then an island surrounded by GDR territory, but belonged to the FRG. Before the erection of the Wall, it was a popular destination 
for people who wanted to migrate to West Germany and who would cross the border in Berlin. Most of them, however, did not settle in Berlin but moved on to one of the other 12 West German states to settle where their relatives or friends lived.

\section{[Insert Figure 3 about here]}

Outside of Berlin and around the rest of the GDR territory, a physically different, but technically very similar 1,393 kilometer (866 miles) long "Inner German Border" was erected (see Figure 2b). This border ran from the Baltic Sea to Czechoslovakia and represented the boundary of the "Iron Curtain." This Wall consisted only partly of cement, but mostly of high metal fences, wires, alarms, watchtowers, and spring guns. Around the Wall, the 500 meter wide "Protective Strip" ("Schutzstreifen") was under tight control. The "Restricted Zone" ("Sperrzone") even entailed an up to 5 kilometer (3.2 miles) wide strip. About 30,000 GDR soldiers projected the whole East-West German border, also referred to as the "Anti-Fascist Protection Rampart" ("Antifaschistischer Schutzwall") by GDR officials. Henceforth, we specifically refer to the border around West Berlin as "Berlin Wall", but also loosely refer to the whole Inner German border as "Wall." For 28 years, from 1961 to 1989, the Wall served as border between the FRG and the GDR. It largely prevented East-West migration, although around 5,000 GDR citizens attempted to escape over the Berlin Wall alone; between 100 and 400 lost their lives at this attempt (Hertle, Nooke, 2009).

After mass demonstrations by the GDR residents, the communist regime decided to allow East-West migration on November 9, 1989. The fall of the Wall was completely unanticipated and unexpected. Some 11 months later, on October 3, 1990, the peaceful German reunification was formalized with the implementation of the "Unification Treaty" ("Einheitsvertrag").

In the first year after the fall of the Berlin Wall, about 400,000 people migrated from East to West Germany (Hunt, 2006). From 1989 to 2005, a total of 3.4 million people migrated from East to West Germany-mainly due to better labor market prospects. At the same time 1.8 million migrated from West to East Germany. Approximately $50 \%$ of the West-East migration was return migration by former GDR residents. Since the reunification, East Germany lost about 
10 percent of its population; after Albania, this represents the second largest net population loss among the countries formerly behind the "Iron Curtain" (Wolf, 2007). The large migration numbers show that it was easy to migrate-last but not least because people and cultures in both parts of Germany were similar, even after 40 years of division.

Summing up, since the end of WWII until today, one should keep three main migration flows in mind: (i) 12 million refugees (Heimatvertriebene) who migrated from pre-WWII eastern German territories before 1950, (ii) 3.6 million people who migrated from the GDR to the FRG between 1950 and 1961, (iii) 3.4 million people who migrated from the former GDR territory to West Germany between 1989 and 2005. Most likely, refugees and migrants do not only sort geographically based on observable (i. e. education) but also on unobservable characteristics (i.e. political ideology).

A large and influential literature uses the division and subsequent reunification of Germany as a natural experiment. Most of these papers derive causal effects from a post-reunification comparison of East and West Germans. One main underlying assumption is the comparability of East and West Germans before the erection of the Berlin Wall, i.e., general socio-economic similarity despite the migration flows (i) and (ii) above. In addition, some studies establish treatment status based on respondents' post-reunification residency status, i.e., depending on the time of the data collection, this data-driven approach may ignore the migration flow (iii) above.

\section{Berlin's Division as a Natural Experiment}

This is the first paper that applies the described well-established and accepted methodology to a microcosm where the main underlying assumptions to establish causality are more likely to hold than for Germany as a whole: the city of Berlin. As shown in Figure 2a, like Germany, Berlin was divided into four occupation zones. During the Cold War, the Soviet Zone was part of the communist GDR, while the other zones belonged to the capitalist FRG (Figure 2b).

One main advantage of the "Berlin approach" is the assumption that East and West Berliners are more similar than East and West Germans in general, pre- and post the 1989 
reunification as well as with and without considering migration flows: First of all, each of the 6 East German and the 12 West German states has a diverse and century-long history. The geography, infrastructure, and culture have been different for centuries (cf. Wolf, 2007). Native populations within a state are certainly more homogenous that populations between different states, i.e., Bavarians differ from Saxons or Hamburgians as do Texians differ from New Yorkers.

Second, in addition to a common history, culture, and infrastructure, Berlin was much less affected by the various forced and voluntary migration flows (i) to (iii) as outlined above. As Figure 4 shows, after WWI, Berlin doubled its population. In contrast, during the last 2 years of WWII, Berlin lost a third, or 1.5 million, of its residents. However, in the crucial time period for the approach used in this paper, between 1950 and 2010, the population of Berlin remained remarkably stable, only varying between 3 and 3.5 million residents (see Figure 4).

\section{[Insert Figure 4 about here]}

As a final strength of our approach, in the two decades following reunification, Berliners were exposed to the same state government, regulation, institutions, and local labor market. Today, without knowing what to look for, it is impossible to tell where the Berlin Wall divided the city prior to 1990 . For example, $15 \%$ of our survey participants did not know whether they live on former GDR or FRG territory.

In our empirical assessment, we focus on Berlin residents and exploit their current and their pre-reunification inner-Berlin place of residency. Knowing the age of the respondents allows us to calculate how many years they were exposed to communist or capitalist living conditions and ideology (see Section 3 for more details).

\subsection{Performance Enhancing Drugs ("Doping") and Sports}

The illegal use of performance-enhancing drugs ("doping") in sport contests is not a new phenomenon. Even in ancient Greece and Rome, athletes experimented with substances such as mushrooms or bull's blood in order to increase the likelihood to win sport contests (cf. Houlihan, 2002). 
After the 1998 Tour de France doping scandal, the World Anti-Doping Agency (WADA) was founded in 1999. The WADA coexists with national anti-doping organizations and aims at a worldwide harmonization of the fight against doping (cf. Kamber, 2011). The WADA AntiDoping-Code defines doping as "the occurrence of one or more of the anti-doping rule violations set forth in Article 2.1 through 2.8 of the Code" (WADA, 2009, page 18). The articles essentially include a list of prohibited substances and specific behavior, such as the possession of prohibited substances or the refusal to submit to sample collection.

The WADA's main tool in its fight against doping is laboratory doping control analysis. Since the 2004 Olympic Games in Greece, according to official WADA doping tests, less than 1\% of all professional athletes dope (Tsivou et al., 2006; Striegel et al., 2010). However, anonymous surveys of top-level athletes find that the actual (lifecycle) prevalence is substantially higher. Pitsch et al. (2007) conduct a web based survey among German top-level athletes and find that between $25 \%$ and $50 \%$ confess to "have ever used banned substances or methods to enhance [their] performance" (p. 89). Striegel et al. (2010), surveying elite level sport adolescents, find a lifecycle doping prevalence rate of about 7\%. Lentillon-Kaestner and Ohl (2011) conclude that, depending on the sample and the framing of the doping question, doping prevalence estimates can vary between 1 and $40 \%$.

In addition to theoretical explanations for why athletes cheat, there exists experimental (Schwieren and Weichselbaumer, 2010), qualitative (Smith et al., 2010; Boodworth and McNamee, 2010) as well as non-experimental quantitative (Humphreys and Ruseski, 2011) studies seeking to explain doping prevalence and attitudes. Obviously, athletes view the use of banned performance-enhancing substances as "unnatural" and "cheating," while legal performance-enhancing substances are considered "essential" for success (Smith et al., 2010, p. 181). The use of banned substances is positively associated with being young and male, as well as exhibiting other risky behavior such as smoking, drinking, or marijuana use (Humphreys and Ruseski, 2011). For an overview about the history and future of doping see Thompson (2012). Dilger et al. (2007) review the theoretical and empirical economic literature on the use of performance-enhancing drugs. 
From a historical perspective, the use of steroids among elite athletes was common in the 1950s and 1960s. Adverse health effects were widely unknown and sanctions impossible to impose due to a lack of methods to detect the use of such substances (Shackleton, 2009).

\section{Doping in the GDR}

Given the size of the GDR, with its 17 million residents, its success at the Olympic Games was striking. In 1968, at the Olympic Games in Mexico City, GDR athletes won 9 gold medals and ranked fifth in the medal table. Fours year later, in Munich's 1972 games, GDR athletes won 20 gold medals and ranked third among all countries worldwide. During Montreal's 1976 Olympics, GDR athletes won 40 gold medals, ranking second in the medal table after the Soviet Union. Given these figures, rumors about systematic doping in the GDR spread widely and its athletes "had the reputation for never getting caught" (Wiese, 2007; Shackleton, 2009, p. 292). Ultimately only one East German athlete was ever convicted of doping and suspended: shotputter llona Slupianek in 1977.

Without any doubt the GDR had an extremely well-developed systematic elite-level athletics furtherance-system that identified and cultivated talents beginning in primary school. Proof of this successful athlete furtherance-system was the extremely high share of successful former GDR residents in reunified German Olympic teams during the 1990s.

After the reunification when the records were opened, it became clear that the GDR implemented and maintained a systematic state doping program. Systematic state-controlled doping started in the 1970s, when the "GDR Ministry for State Security" ("Staatssicherheit", the so-called "Stasi") started supervising systematic doping practices. This became a state policy

under the name "State Plan 14.25." A doping testing laboratory in Kreischa (Saxony) performed 12,000 annual tests on East German athletes. However, the objective was not to penalize athletes, but to develop scientific methods to avoid positive tests at official contests. The statedirected "Research Institute for Physical Culture and Sport" ("Forschungsinstitut für Körperkultur und Sport, FKS") employed 600 and performed 21 doping research projects between 1984 and 1988 alone (Spitzer, 2003; Müller and Hartmann, 2009). 
The regime-run doping program systematically kept athletes in the dark. Even 10 year old athletes were forced to take the "vitamin pills" by their coaches. Those who did not obey were suspended (Bachner, 2010). After the German reunification, it came to light that dozens of athletes were experiencing negative long-term health effects caused by their forced early age drug abuse. Several lawsuits against former coaches and state officials were filed. In 2002, a Doping-Victim-Assistance Law ${ }^{1}$ was implemented at the federal level. Based on this law, about 200 victims were granted a one-time compensation of about $€ 10,000$ (Hettfleisch, 2010). Note that the doping scandal was widely discussed in the common German media that both East and West Berliners are exposed to in the same manner. Thus media exposure does not confound our results.

In total, estimates suggest that around 12,000 GDR elite athletes were given performanceenhancement drugs without their knowledge or consent (Müller and Hartmann, 2009). Given an average population size of about 17 million people, this means that 1 out of every 1,400 GDR residents was personally affected. This is important since it suggests that, in our Berlin survey, not more than one or two respondents might have been personally affected by the regime-run doping system (see Section 3.1 below). Consequently, interviewed victims of GDR doping do not bias our estimates. Our intention is to elicit attitudes toward doping from respondents who knew the GDR furtherance system well enough-since they were former athletes-and could have been potentially, but were not actually, affected by the doping crimes of the GDR regime.

\section{Data: A Survey of Berliners}

Between August 9 and September 30, 2011, we conducted a telephone and online survey of 7,000 Berlin residents. A quarter of all interviews were conducted by telephone and three quarters online. Respondents were randomly selected. However, in order to increase sample size via internet, the survey is not strictly representative.

\footnotetext{
1 “Gesetz über eine finanzielle Hilfe für Doping-Opfer der DDR,” passed 24. August 2002, BGBI. I Nr. 62., §3410.
} 
Comparing the raw demographics of our survey with household panel data from the nationally representative German Socio-Economic Panel Study (SOEP) illustrates some differences (cf. Wagner et al., 2007). According to the SOEP, in 2010, the average resident of Berlin was 51 years old, whereas our survey yields only an average age of 41.5 (see Appendix B). Comparing gender ( $54 \%$ vs. $58 \%$ ), marital status ( $24 \%$ vs. $35 \%$ single), and employment status ( $37 \%$ vs. $44 \%$ full-time employed) shows that the differences are not extreme, but that our sample is younger, includes more singles and full-time employees. However, because we are not interested in representative descriptive figures, but in regression analyses to detect differences in East-West response behavior, non-representativeness is not a threat to our findings.

\subsection{Sample Selection and Variables of Interest}

Appendix A displays the wordings of the most important questions asked in the survey. ${ }^{2}$ Question A refers to the residency of the respondents (or the mother of the respondent) before German reunification. Approximately $60 \%$ of all respondents were already living in Berlin before the reunification, with $30 \%$ living in other German states before 1989 . We drop the $5 \%$ (319 obs.) of the sample that lived neither in Germany nor Eastern Europe before 1989 (category (f) of Question A in Appendix A). We also drop respondents who did not respond to this residency question or to either Questions B or $C$. The remaining sample consists of 5,877 Berliners.

In our main model, we focus solely on native Berliners, i.e., respondents who lived in Berlin for more than 22 years (answers (a) and (b) to Question A in Appendix A). Accordingly, we generate a dummy called GDR that is zero for those who lived in West Berlin before 1989. GDR is one for respondents who lived in East Berlin before 1989. This is our main variable of interest. Note that we construct this main variable of interest according to the pre-reunification residency status, not current residency. The sample size in our main model is $3,913.57 \%$ of the respondents were socialized in West Berlin and 43\% were socialized in East Berlin pre-1989.

\footnotetext{
${ }^{2}$ The large majority of respondents answered the survey in German. We translated the survey questions into English.
} 
In our robustness check, we make use of the full sample. Here, we compare

- those who were living (i) in East Berlin, (ii) in one of the other states of the former GDR, or (iii) in one of the former Eastern bloc countries to those

- who were socialized in (j) West Berlin or (jj) West Germany

(categories (a), (c), (e) vs. (b), (d) of Question A in Appendix A).

Question C of Appendix A asks whether respondents are currently or were earlier in their lives athletes in an "extramural sports club." In Germany, many children begin to participate in regular sport sometime between age 5 and 15 but, unlike in the US, the sports practices are not associated with primary or secondary schools. Instead these extramural sports clubs typically operate as non-profit amateur organizations focusing on a particular type of sport (e.g. soccer, basketball, rugby, etc). Almost every village has one or more such clubs. In general, the clubs charge very low membership fees and generally admit anyone who applies to be a member. Some clubs in bigger cities that have many members may participate in sports leagues that are professional or semi-professional.

A significant number of youths join extramural sports clubs in Germany. If a youth is serious about the particular sport, that is if she decides she wants to acquire, develop, and hone the skills the sport involves, she will often practice 2 to 5 times a week, join a team in their age group and participate in amateur competitions. This aspect of the extramural sports clubs closely resembles the sort of activities US youth pursue when they join school-based sports teams. As in the US, German youth compete in matches that occur in their home village and they travel to compete in matches hosted by clubs of neighboring villages. The competitions and the associated travel are integral part of the experience Germany youth gain when they participate in extramural sports clubs.

We drop those 156 respondents who are still active in extramural competitive sports and focus on those with past and serious involvement as one variable of interest. EliteAthlete is one for those with past extramural sports experience (category (b) of Question C) and zero else. The 
share of past athletes is almost identical for respondents who were socialized in East Berlin (22.4\%; 476 obs.) vs. West Berlin (22.8\%; 406 obs.).

\subsection{Dependent Variables: Attitudes toward Doping in Elite-Level Sports}

Exploiting Question B of Appendix A, we generate four dependent variables on doping attitudes. Collapsing individual agreement or disagreement with statements $(a)$ through $(d)$ of Question B, we generate four dummy variables.

About $40 \%$ of all respondents agree with statement (a) ("Doping has always existed, will always exist, and is an unavoidable part of professional sports.") and (c) ("The system of professional sports itself is to blame for doping. The athletes are only the victims.").

About $30 \%$ of all respondents agree with statement (b) ("The state should do everything to ban doping. Doping offenders should be heavily punished.") and (d) ("Those who really want to, can be successful in professional sports without doping.").

\subsection{Other Covariates}

Appendix B shows the descriptive statistics of the covariates that we surveyed and use in the empirical part. In addition to the variables female, age, single, and fulltimeemployed, we also know whether people own property (homeowner) and have a university degree (university). Moreover, we have information on the number of household members under 16 ( $h$ h_member16) as well as the total number of household members ( $h$ __member). Individuals indicated their gross annual household income according to 10 income categories (income). The lowest category is "€0 to $€ 5,000$ " and the highest "more than $€ 100,000$."

\section{Empirical Method and Results}

The next subsection describes our main empirical approach. Afterwards, we assess whether East and West Berliners are comparable along observable dimensions, present regression results, and discuss our findings. 


\subsection{Empirical Approach}

We follow the convention in the literature and estimate the following baseline model:

$$
y_{i}=\beta_{0}+\beta_{1} \text { ExAthlete }_{i, t-T}+\beta_{2} G D R_{i, t-22}+\beta_{3} G D R_{i, t-22} \times \text { ExAthlete }_{i, t-T}+\mathrm{X}_{i}^{\prime} \gamma+\varepsilon_{i}
$$

where $y_{i}$ is one of the dependent variables that measure the individual's attitude toward doping. ExAthlete ${ }_{i, t-T}$ indicates whether the individual is a former athlete and $G D R_{i, t-22}$ is one if the respondent had her residency in East Berlin prior to 1989. $\mathrm{X}_{i}$ represents the remaining control variables and $\varepsilon_{i}$ is the error term. $\beta_{1}$ indicates whether former elite-level athletes have a different attitude toward doping than people who never were athletes. $\beta_{2}$ yields whether socialization in the communist GDR vs. the capitalist FRG-in terms of residing in East rather than West Berlin-has any systematic impact on attitudes. $\beta_{3}$ is the interaction term and yields the effect of being a former athlete in the GDR. To capture effects that stem from personal GDR socialization experience, we restrict the sample in the baseline model to individuals who were at least 18 years old when the Wall fell in $1989 .^{3}$

The second model that we estimate is more flexible than the baseline model. Here, we use the full sample and explicitly focus on the pure age effect on attitudes $\left(\alpha_{3} A G E_{i}\right)$, the interaction effect between age and being a former athlete $\left(\alpha_{5} A G E_{i} \times\right.$ ExAthlete $\left._{i, t-T}\right)$, the interaction effect between age and GDR socialization $\left(\alpha_{6} A G E_{i} \times G D R_{i, t-22}\right)$ as well as the triple interaction term between age, GDR socialization, and former athlete status $\left(\alpha_{6} A G E_{i} \times G D R_{i, t-22} \times\right.$ ExAthlete $\left._{i, t-T}\right)$.

$$
\begin{aligned}
y_{i}= & \alpha_{0}+\alpha_{1} \text { ExAthlete }_{i, t-T}+\alpha_{2} \text { GDR }_{i, t-22}+\alpha_{3} \text { AGE }_{i} \\
& +\alpha_{4} G D R_{i, t-22} \times \text { ExAthlete }_{i, t-T}+\alpha_{5} A G E_{i} \times \text { ExAthlete }_{i, t-T}+\alpha_{6} A G E_{i} \times G D R_{i, t-22} \\
& +\alpha_{7} A G E_{i} \times G D R_{i, t-22} \times \text { ExAthlete }_{i, t-T} \\
& +\mathrm{X}_{i}^{\prime} \gamma+\varepsilon_{i}
\end{aligned}
$$

\footnotetext{
${ }^{3}$ This is the equivalent of being at least 40 years old at the time of the survey.
} 
We estimate Linear Probability Models (LPM) for the sake of clarity and transparency. We checked that probit regressions do not alter the findings. The sizes of the coefficients are very similar, as are the levels of statistical significance. The results are available upon request.

\subsection{Balancing properties of observables}

One main objective of this paper is to assess the impact of state socialization by focusing on current residents of Berlin who lived in this city before 1989. Treatment status is defined according to whether people lived in the Eastern or Western part of the city before the fall of the Wall. This approach intends to shut down potentially confounding impact factors stemming from diverging economic performances, disappointed expectations, or East-West migration. These factors could potentially bias estimates that rely on comparing people living currently in East and West Germany.

One statistical measure to assess the similarity of treatment and control groups is the "normalized difference" (see notes to Table 1 for more details). A normalized difference exceeding 0.25 indicates that subsamples are significantly different on the dimension examined, which might lead to sensitive treatment estimates (Imbens and Wooldridge, 2009). Table 1 shows the mean values for our set of observables. Column (3) displays the normalized difference for each covariate. We find that all observables are reasonably well balanced. None of the normalized differences exceeds the threshold value of 0.25 . All values are below 0.2 and 7 of the 9 normalized differences are even below 0.1 .

\section{[Insert Table 1 about here]}

\subsection{Regression results}

\section{Model A: Baseline Specification}

Table 2 gives the results of the baseline specification as outlined in equation (1). For the sake of clarity and brevity, we suppress the coefficient estimates of those covariates that are not of principle interest. In the even numbered columns, these covariates are included in the regressions, whereas they are excluded in the odd numbered columns. Note that the results are 
robust to the inclusion of additional sample composition adjusters. Each column represents one regression model. We run four different models with four different dependent variables indicating individuals' attitudes and beliefs toward the use of performance-enhancement drugs (see Section 3.2).

\section{[Insert Table 2 about here]}

Looking at the overall pattern of results in Table 2, we find that being a former athlete has a large impact on attitudes toward doping. Among the group of former athletes, we observe a significant 5 to 6 percentage point larger fraction of respondents-as compared to nonathletes-who agree with the following statements.

- The state should do everything to ban doping. Doping offenders should be heavily sanctioned.

- The system of professional sports itself is to blame for doping. The athletes are only the victims.

- $\quad$ Those who really want to, can be successful in professional sports without doping.

The level estimates for being socialized in East Berlin prior to 1989 are close to zero and insignificant in most cases. However, the coefficient estimate that indicates agreement with the statement "The system of professional sports itself is to blame for doping. The athletes are only the victims." is relatively large (4ppt.) and significant at the $10 \%$ level. This suggests that former GDR residents are more likely to blame system effects and structural circumstances for the doping issue in sports and are more likely to see athletes as victims. This fits very well to the history of doping in the GDR and the systematic abuse of underage elite-level athletes, who were doped without their knowledge and suffered significant negative long-term health consequences (see Section 2.2).

Note that the systematic communist doping machinery became public and was widely debated during the 1990s, with people in East and West Berlin experiencing identical exposure 
to the German media. Today, the systematic doping in the GDR is no longer a big issue in the media.

Looking at the interaction term between GDR socialization and being a former athlete yields relatively large coefficients between 4 and 8 ppt., but they are imprecisely estimated in most cases. However, respondents who were former athletes and who were socialized in the former GDR have an 8 ppt. higher probability to agree with the statement: "Doping has always existed, will always exist, and is an unavoidable part of professional sports." This can be interpreted as a retrospective justification of the furtherance system practices in the GDR. Note that it is highly unlikely that a significant share of these respondents was personally and physically affected by the GDR doping practices. However, since they were former active athletes, they were part of the GDR furtherance system. An alternative interpretation could refer to as helplessness or resignation.

\section{Model B: Flexible Specification}

Now we run a more flexible specification that investigates the age effect more thoroughly. We estimate models as displayed in equation (2).

\section{[Insert Table 3 about here]}

First, we can confirm our finding from above that individual characteristics, such as being a former athlete and age, systematically and strongly impacts attitudes toward performanceenhancement drugs. Independent of state socialization, older people and former athletes are less likely to believe that doping is "normal" in professional sports (column (1)). This finding is in line with the scant empirical literature on this topic (Bloodworth and McNamee (2010)). In contrast, older people are more likely to believe that athletes are victims of the system (column (3)).

Former athletes have a $24 \mathrm{ppt}$. higher probability to take the view that athletes can be successful without using illegal performance enhancement drugs. Note that this strong and positive association is not necessarily a causal effect triggered by the experience of having 
exercised intensively at younger ages. However, first of all, we exclude current athletes in our models. By focusing on former athlete status we intend to exclude reverse causality issues. Second, the associations could theoretically represent a selection on unobservables story. However, remember that those who practice high-level sports typically start as teens or even younger. ${ }^{4}$ It is very plausible that participating in extramural competitive sports from early childhood on for a longer period of time-with all its components such as intensive training, regular contests, and the very competitive environment-heavily influences people's personality and, thus, their attitudes and values for the rest of their lives. Nevertheless, we speak of associations and do not claim that differences in attitudes were unambiguously causally triggered by exercising in younger ages.

Second, we find that state socialization exerts a long-lasting significant impact on attitudes that may either reinforce or offset the plain Age or ExAthletes effect. Note that the state socialization effect mostly unfolds itself in combination with these individual level predictors. There is only one statement where we obtain a 9 ppt. higher agreement rate among former GDR residents, independent of age and being a former athlete: Berliners who were socialized in East Berlin are 9 percentage points more likely to believe that doping is an unavoidable part of professional sports than West Berliners (column (1)). For every 10 years of older age, the effect is offset by 2 percentage points.

A similarly interesting pattern is observed in column (2). Former GDR residents who experienced the system of high-level sports at younger ages are almost $20 \mathrm{ppt}$. less likely to hold the opinion that doping offenders should be heavily sanctioned. However, for every 10 years of life age, this attitude differential is diminished by 5 percentage points.

An almost identical observation can be made when we look at column (4): Former GDR athletes are $22 \mathrm{ppt}$. less likely to believe that athletes can be successful without doping if they really wanted to. And again, for every 10 years of older age, this significant gap in attitudes shrinks by 5 percentage points.

\footnotetext{
${ }^{4}$ See last three paragraphs of Section 3.1 for a discussion of the German amateur sports system.
} 
It is remarkable that especially younger former GDR residents have a significantly different attitude than their FRG socialized peers. This is plausible since GDR doping activities peaked in the 70s and 80s when the younger half of our survey respondents were at an age when they may have been affected by the GDR doping practices. Take as an example the responses to column (4): If we split the sample and solely focus on those 40 years of age or younger, i.e., the generation born in the 1970s, we find that former athletes in general are 18.6 ppt. more likely (p-value: <1\%) to agree with the statement: "Those who really want to, can be successful in elite-levels without doping." However, former GDR athletes are 10 ppt. less likely (p-value: 7\%) to agree with this statement. Focusing on respondents aged 50 and above, i.e., those who were born in the 1960s and earlier, the difference between East and West Berliners vanishes entirely both in size and significance.

\section{Model C: Robustness Check Including post-1989 Migrant Sorting into Berlin}

So far we restrict our sample to current Berlin residents who indicated that they lived in Berlin before the fall of the Berlin Wall in 1989. Now, we incorporate people who migrated to Berlin since the fall of the Wall. This includes people from East Germany, as well as West Germany, who did not live in Berlin before 1989. Including current Berlin residents who migrated in, increases our sample size by almost $50 \%$ to 5,877 respondents.

This robustness check assesses the effect of ignoring post-1989 East-West or West-East migration patterns when exploiting the German division and subsequent reunification as natural experiment. Note, however, that treatment status is still established based on the pre1989 residency. Respondents who were socialized in East Germany or one of the former communist bloc states are assigned to the treatment group that measures the GDR socialization effect.

\section{[Insert Table 4 about here]}

Table 4 gives us the results when we run our flexible specification model. The overall pattern of results as well as the size and significance of the coefficients is remarkably close to 
what we find in Table 3. Former athletes who were socialized in the GDR are 20 ppt. less likely to hold the opinion that

- doping offenders should be heavily sanctioned and

- athletes can be successful without taking performance-enhancement drugs.

This difference in attitudes decreases significantly with age.

Contrarily, people who were socialized under the communist regime are 10 ppt. more likely to believe that doping is normal in professional sports (column (1)). Again, this difference in attitudes shrinks with increasing age. Overall, these results are almost identical compared to the smaller sample that excludes 2,000 new-Berliners. In the first place, the larger sample size increases the power and the precision of our estimates.

These findings suggest that East and West Germans who migrated after 1989 to Berlin resemble "original" East and West Berliners who had been socialized in Berlin. This could be the result of (i) an assimilation process; (ii) self-selection based on un(observables); or (iii) general similarities between East Germans and East Berliners as well as West Germans and West Berliners, e.g., as a result of GDR vs. FRG state socialization.

\section{Model D: Robustness Check with Current East-West Residency as Treatment Status}

As a last exercise, we test whether totally ignoring any post-1989 East-West migration would substantially bias our estimates. Therefore, we define treatment status based on the current rather than the pre-1989 residency. Interestingly and in line with the historic evidence about the division and reintegration of Berlin (see Section 2.1), there is a relatively large number of 600 respondents who do not know whether they currently live in former East or West Berlin. This illustrates that the old physical borders become indistinct in the minds of the Berliners today. Note that they were all well aware of their pre-1989 residency.

As a second interesting point, as a matter of fact, intra-Berlin geographic mobility seems to be relatively low. As Table 1 nicely illustrates, among those East Berliners who were also 
socialized in East Berlin pre-1989, 86\% still live in East Berlin. Only 8\% of pre-1989 West Berliners live in East Berlin.

\section{[Insert Table 5 about here]}

Table 5 applies the same four models as above. The general conclusion from this exercise seems to be clear: The overall pattern of results remains robust although the precision of our estimates decreases and the sizes of the coefficients shrink slightly. For example, in columns (1) and (2), the magnitudes of four coefficient estimates decrease and they are no longer significant at conventional statistical levels.

This finding makes sense since ignoring post-reunification migration essentially introduces additional measurement error to our models. We conclude that, in a German reunification natural experiment setting, using current instead of pre-1989 residency status does not alter the main findings, although measurement error leads to attenuation bias and less precise estimates.

\section{Discussion and Conclusion}

This paper shows that state socialization shapes values in the long-run. Even 20 years after the peaceful German reunification, we detect significant differences in attitudes and beliefs between people who were socialized in former East vs. West Berlin. We compare and contrast the top-down state socialization effect with the impact of a bottom-up effect-the latter stemming from individual characteristics such as age or specific individual life experience. We find that both state socialization and individual experience matter to a similar extent-and that they unfold their strongest predicative power in interaction.

On methodological grounds, we improve upon the existent post-Cold War literature by focusing on the Berlin microcosm and its division rather than the whole of Germany. First, the apparent attractiveness of this approach is the closer similarity of East and West Berliners as compared to all East and West Germans. Second, in addition to a common pre-Cold War history, Berliners had a common post-reunification history with unitary institutions, a uniform 
state government, and an integrated labor market. Finally, the Berlin-approach makes it possible to eliminate post-1989 migration as a confounding factor since we can track the pre1989 residency status of our respondents. We find that Berlin-specific sorting as well as migration patterns since 1989 decrease the estimates' precision and downward bias the estimates, but do not alter the main results.

On contextual grounds, we investigate the long-term impact of socialization in a totalitarian vs. a democratic state on values and attitudes toward doping. We deliberately chose this topic since, under State Plan 14.25, the communist regime of the German Democratic Republic (GDR) systematically administered performance-enhancement drugs to their top-level athletes, in most cases without the athletes' knowledge or consent. These systematic doping activities were revealed and comprehensively discussed in the German media during the 1990s. Even more than 20 years after the peaceful reunification, we still find significant differences in attitudes toward doping behavior. This demonstrates that state socialization has a long-lasting impact. This long-lasting effect could either manifest itself through direct personal experience-e.g. among those who were active former athletes-or indirectly-through a form of emotional solidarity and justification with the state in which people were raised and socialized.

Our findings have important policy-relevant implications for a number of topics. Western democracies have experienced on many occasions that social norms and values are extremely difficult to influence in the short-run. Obviously, decade-long exposure to specific state policies, especially in interaction with personal life experience, has a long-term impact on attitudes and beliefs. This paper specifically shows that this holds for attitudes toward health behaviors. A related and highly relevant example in Western democracies would be the effectiveness of decade long public health anti-smoking policies. Western state policies basically banned smoking in public and introduced new social norms that made smoking a very unpopular, bad habit. In light of our findings, it is very likely that these policies have a long-lasting impact on values, even absent restrictive policies. 


\section{Literature}

Acemoglu, D.; Johnson, S.; Robinson, J. A. (2001): "The Colonial Origins of Comparative Development: An Empirical Investigation," American Economic Review, 91(5): 1369-1401.

Aghion, P.; Algan, Y.; Cahuc,P.; Shleifer, A. (2010): "Regulation and Distrust," The Quarterly Journal of Economics, 125(3): 1015-1049.

Alesina, A.; Fuchs-Schündeln, N. (2007): "Good Bye Lenin (Or Not?): The Effect of Communism on People's Preferences," American Economic Review, 97(4): 1507-1528.

Alesina, A.; Giuliano, P. (2011): "Family Ties and Political Participation," Journal of the European Economic Association, 9(5): 817-839.

Algan, Y; Cahuc, P. (2010): “Inherited Trust and Growth," American Economic Review, 100(5): 2060-2092.

Bachner, Frank (2010): “Doping in der DDR: 'Da läuft mir die Galle über',“ Zeit, September 16, 2010, available at http://www.zeit.de/sport/2010-09/doping-ddr-boese-koehler, last access on March 21, 2012.

Bauer, T.; Braun, S.; Kvasnicka, M. (2013): "The Economic Integration of Forced Migrants:

Evidence from Germany," Economic Journal, forthcoming.

Becker, S. O.; Boeckh, K.; Hainz, C.; Wößmann, L. (2011): “The Empire Is Dead, Long Live the Empire! Long-Run Persistence of Trust and Corruption in the Bureaucracy," IZA Discussion Papers 5584.

Beer, M. (2011): Flucht und Vertreibung der Deutschen. Voraussetzungen, Verlauf, Folgen. C.H. Beck,München.

Bethlehem, S. (1999): Heimatvertreibung, DDR-Flucht, Gastarbeiterzuwanderung. Klett-Cotta, Stuttgart.

Bird, E. J.; Wagner, G. G. (1997): "Sport as a Common Property Resource: A Solution to the Dilemma of Doping," Journal of Conflict Resolution, 41(6): 749-766.

Blanchflower, D. G.; Freeman, R. (1997): "The Attitudinal Legacy of Communist Labor Relations," Industrial and Labor Relations Review, 50(3): 438-459.

Bloodworth A.; McNamee M. (2010): “Clean Olympians? Doping and Anti-Doping: the Views of Talented Young British Athletes," International Journal of Drug Policy, 21(4): 276-282.

Brosig-Koch, J.; Helbach, C.; Ockenfels, A.; Weimann, J. (2011): "Still Different After All These Years: Solidarity Behavior in East and West Germany," Journal of Public Economics, 95(11): 1373-1376. 
Burchardi, K. B.; Hassan, T. A. (2013):"The Economic Impact of Social Ties: Evidence from German Reunification," Quarterly Journal of Economics, forthcoming.

Burda, M. C. (2006): "Factor Reallocation in Eastern Germany after Reunification," American Economic Review, 96(2): 368-374.

Bursztyn, L.; Cantoni, D. (2012): "A Tear in the Iron Curtain: The Impact of Western Television on Consumption Behavior," CEPR Discussion Papers 9101, C.E.P.R. Discussion Papers.

Carpenter, C. (2005): "Youth Alcohol Use and Risky Sexual Behavior: Evidence from Underage Drunk Driving Laws," Journal of Health Economics, 24(3: 613-628.

Cawley, J.; Ruhm, C. J. (2011): "The Economics of Risky Health Behaviors" Handbook of Health Economics, Volume 2, Chapter 3: 95-199.

Crost, B.; Rees, D.I. (2013): "The Minimum Legal Drinking Age and Marijuana Use: New Estimates from the NLSY97," Journal of Health Economics, forthcoming.

Dilger, A.; Frick, B.; Tolsdorf, F., (2007): “Are Athletes Doped? Some Theoretical Arguments and Empirical Evidence," Contemporary Economic Policy, 25(4): 604-615.

Eugster, B., Lalive, R., Steinhauer, A., Zweimüller, J. (2011): “The Demand for Social Insurance: Does Culture Matter?" The Economic Journal, 121(556): F413- F448.

Frijters, P.; Haisken-DeNew, J. P.; Shields, M. A., (2004): "Money Does Matter! Evidence from Increasing Real Income and Life Satisfaction in East Germany Following Reunification," American Economic Review, 94(3): 730-740.

Frijters, P.; Haisken-DeNew, J. P.; Shields, M. A., (2005): "The Causal Effect of Income on Health: Evidence from German Reunification," Journal of Health Economics, 24(5): 997-1017.

Fuchs-Schündeln, N. (2008): "The Response of Household Saving to the Large Shock of German Reunification," American Economic Review, 98(5): 1798-1828.

Fuchs-Schündeln, N.; Schündeln, M. (2005): "Precautionary Savings and Self-Selection: Evidence from the German Reunification Experiment," Quarterly Journal of Economics, 120(3): 10851120.

Gerlach, K.; Levine, D.; Stephan, G.; Struck, O., (2008): "Fairness and the Employment Contract: North American Regions Versus Germany," Cambridge Journal of Economics, 32(3): 421-439.

Grosjean, P.; Senik, C. (2011): “Democracy, Market Liberalization, and Political Preferences,” The Review of Economics and Statistics, 93(1): 365-381.

Hertle, H.-H.; Nooke, M. (2009): Die Todesopfer an der Berliner Mauer 1961-1989. Ein biographisches Handbuch. Ch. Links, Berlin. 
Hettfleisch, W. (2010): „DDR-Doping - Im Land des Leugnens,“ Frankfurter Rundschau, January 27, 2010, available at http://www.fr-online.de/doping/ddr-doping-im-land-desleugnens,1473470,2677600.html, last accessed on March 21, 2012.

Houlihan, B. (2002): Dying to Win: Doping in Sport and the Development of Anti-Doping Policy, $2^{\text {nd }}$ edition, Council of Europe Publishing, Strasbourg, Cedex.

Humphreys, Brad R.; Ruseski, Jane E., (2011): "Socio-Economic Determinants of Adolescent Use of Performance Enhancing Drugs: Evidence from the YRBSS," The Journal of Socio-Economics, 40(2): 208-216.

Hunt, J. (2006): "Staunching Emigration from East Germany: Age and the Determinants of Migration," Journal of the European Economic Association, 4(5): 1014-1037.

Lillard, D.R.; Molloy, E.; Sfekas, A. (2013): "Smoking Initiation and the Iron Law of Demand," Journal of Health Economics, 32(1): 114-127.

Kamber, M. (2011): "Development of the Role of National Anti-Doping Organisations in the Fight Against Doping: From Past to Future," Forensic Science International, 213(1-3): 3-9.

Lentillon-Kaestner, V.; Ohl, F. (2011): “Can We Measure Accurately the Prevalence of Doping?" Scandinavian Journal of Medicine \& Science in Sports, 21(6): e132-e142

Luttmer, E. F. P.; Singhal, M. (2011): “Culture, Context, and the Taste for Redistribution," American Economic Journal: Economic Policy, 3(1): 157-179.

Malmendier, U.; Nagel, S. (2011): “Depression Babies: Do Macroeconomic Experiences Affect Risk Taking?" The Quarterly Journal of Economics, 126(1): 373-416.

Mee, C. L. (1977): Die Teilung der Beute: Die Potsdamer Konferenz 1945. Fritz Molden, Muenchen.

Müller, U.; Hartmann, G. (2009): Vorwärts und Vergessen! Kader, Spitzel und Komplizen - Das gefährliche Erbe der SED-Diktatur, 1st edition, Rowohlt Berlin.

Pitsch, W., Emrich, E., Klein, M. (2007): “Doping in Elite Sports in Germany: Results of a www survey," European Journal for Sport and Society 4(2): 89-102.

Pryor, F. L. (2007): "Culture and Economic Systems," American Journal of Economics and Sociology, 66(2): 817-855.

Rainer, H.; Siedler, T. (2009): “Does Democracy Foster Trust?" Journal of Comparative Economics, 37(2): 251-269.

Rashad, I.; Kaestner, R. (2004): "Teenage Sex, Drugs and Alcohol Use: Problems Identifying The Cause of Risky Behaviors," Journal of Health Economics, 23(3): 493-503. 
Schwieren, C.; Weichselbaumer, D. (2010): "Does Competition Enhance Performance or Cheating? A laboratory experiment," Journal of Economic Psychology, 31(3): 241-253.

Shackleton,C. (2009): "Steroid Analysis and Doping Control 1960-1980: Scientific Developments and Personal Anecdotes," Steroids, 74(3): 288-295.

Shiller, R. J.; Boycko, M.; Korobov, V. (1991): "Popular Attitudes toward Free Markets: The Soviet Union and the United States Compared," American Economic Review, 81(3): 385-400.

Sinn, H.-W. (2002): "Germany's Economic Unification: An Assessment after Ten Years," Review of International Economics, 10(1): 113-128.

Smith, A.C.T.; Stewart, B.; Oliver-Bennetts, S.; McDonald, S.; Ingerson, L.; Anderson, A.; Dickson, G.; Emery, P.; Graetz, F. (2010): "Contextual Influences and Athlete Attitudes to Drugs in Sport," Sport Management Review, 13(3): 181-197.

Spitzer, G. (2003): Doping in der DDR. Ein historischer Überblick zu einer konspirativen Praxis. Genese-Verantwortung-Gefahren. 3rd edition.

Statisisches Bundesamt (1953): Statistisches Jahrbuch für die Bundesrepublik Deutschland 1952, available at www.digizeitschriften.de, last accessed on March 22, 2012.

Striegel, H.; Ulrich, R.; Simon, P. (2010): “Randomized Response Estimates for Doping and Illicit Drug Use in Elite Athletes," Drug and Alcohol Dependence, 106(2-3): 230-232.

Szymanski, S. (2003) "The Economic Design of Sporting Contests," Journal of Economic Literature, 41(4): 1137-1187.

Tabellini, G. (2008): "Presidential Address Institutions and Culture," Journal of the European Economic Association, 6(2-3): 255-294.

Thompson, Helen (2012): “Superhuman Athlets," Nature, 487(157): 287-289.

Tsivou, M.; Kioukia-Fougia, N.; Lyris, E.; Aggelis, Y.; Fragkaki, A.; Kiousi, X.; Simitsek, Ph.; Dimopoulou, H.; Leontiou, I.-P. ; Stamou, M.; Spyridaki, M.-H.; Georgakopoulos, C. (2006): “An Overview of the Doping Control Analysis During the Olympic Games of 2004 in Athens, Greece," Analytica Chimica Acta, 555(1): 1-13.

Uhlig, H. (2006):"Regional Labor Markets, Network Externalities and Migration: The Case of German Reunification," American Economic Review, 96(2): 383-387.

Wagner, G. G., Frick, J. R., Schupp, J. (2007): "The German Socio-Economic Panel Study (SOEP) Evolution, Scope and Enhancements." Journal of Applied Social Science Studies (Schmollers Jahrbuch), 127(1): 139-169 
Wiese, R. (2007): "Staatsgeheimnis Sport - Die Abschottung des Leistungssportsystems der DDR,“ Historical Social Research / Historische Sozialforschung, 32(1): 154-171.

Wolff, S. (2007) : "Prognosen zur Ost-West-Wanderung nach der deutschen Wiedervereinigung," Diskussionsbeiträge aus dem Volkswirtschaftlichen Seminar der Universität Göttingen, No. 132.

Wolf, N. (2009): "Was Germany Ever United? Evidence from Intra- and International Trade, 1885-1933," The Journal of Economic History, 69(3): 846-881.

World Anti Doping Agency (WADA) (2009): World Anti-Doping Code, revised version as of January 1, 2009; available at www.wada-ama.org, last accessed on March 21, 2012. 


\section{Figures and Tables}

\section{Figure 1:}

\section{Germany after the Second World War, 1945}

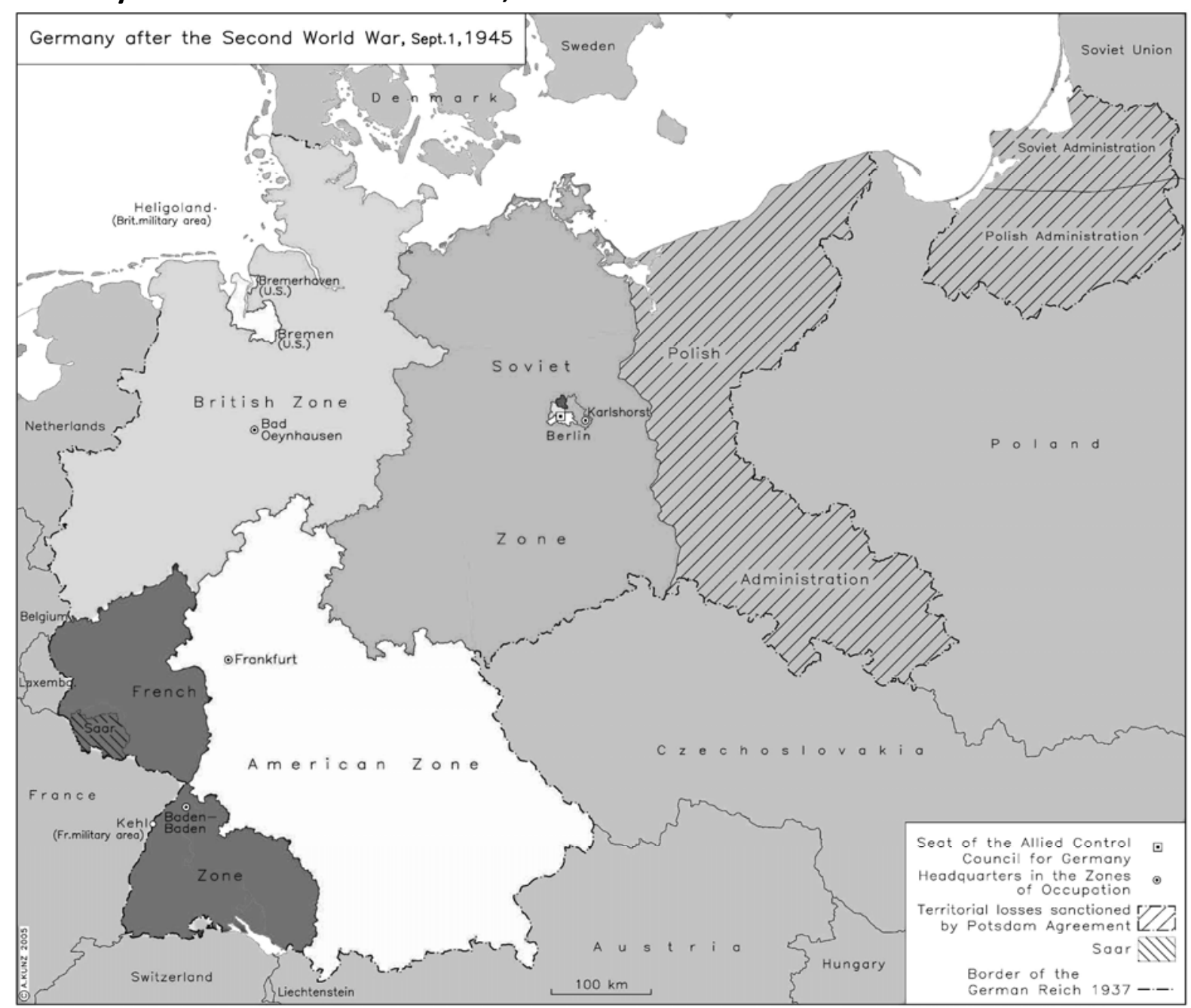

Source: IEG-Maps, Institute of European History, Mainz; available at http://germanhistorydocs.ghi-dc.org/, last accessed on March 6, 2013. 
Fiqure 2a: Division of Germany, 1947

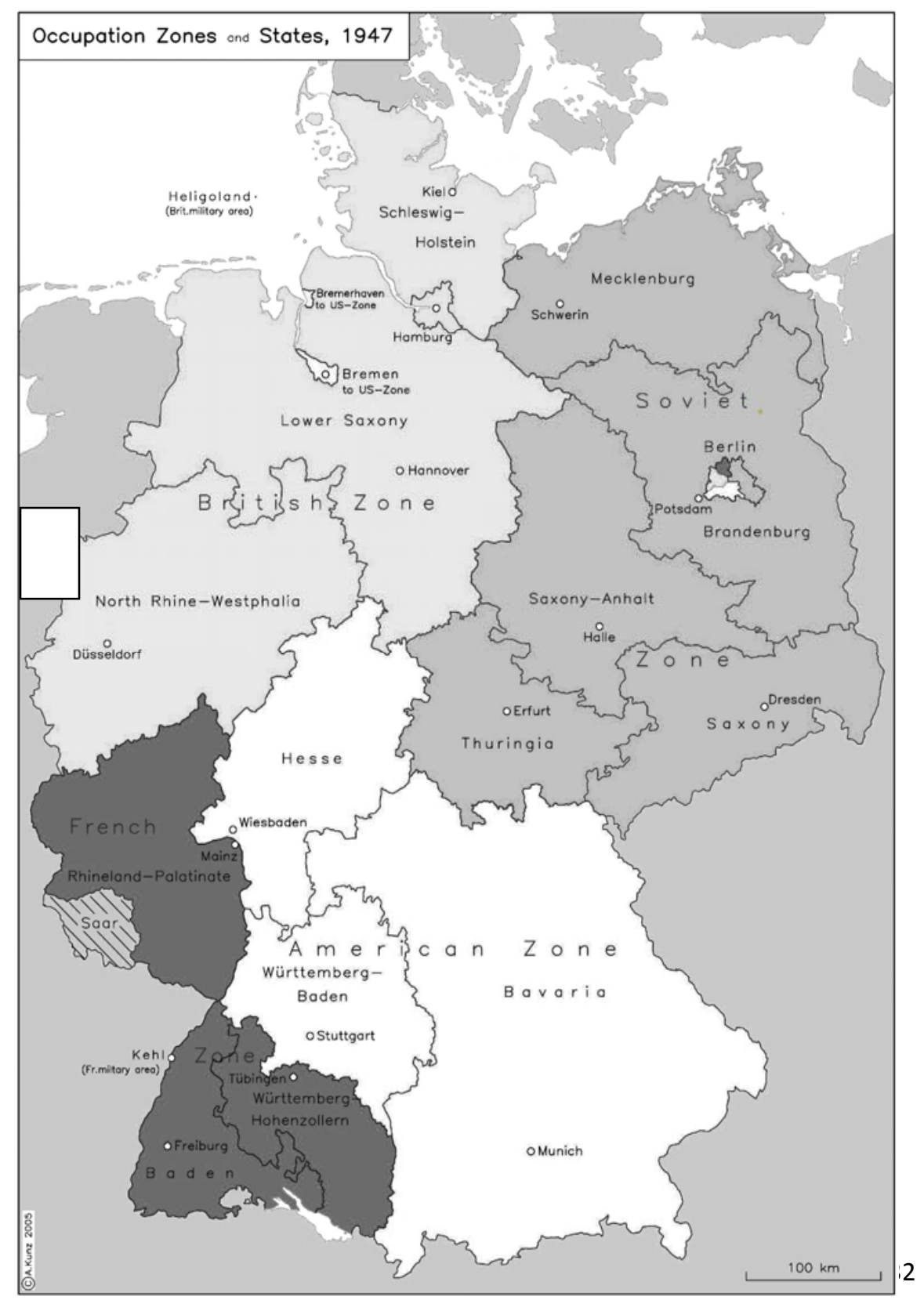

Figure 2b: Division of Germany, 1961

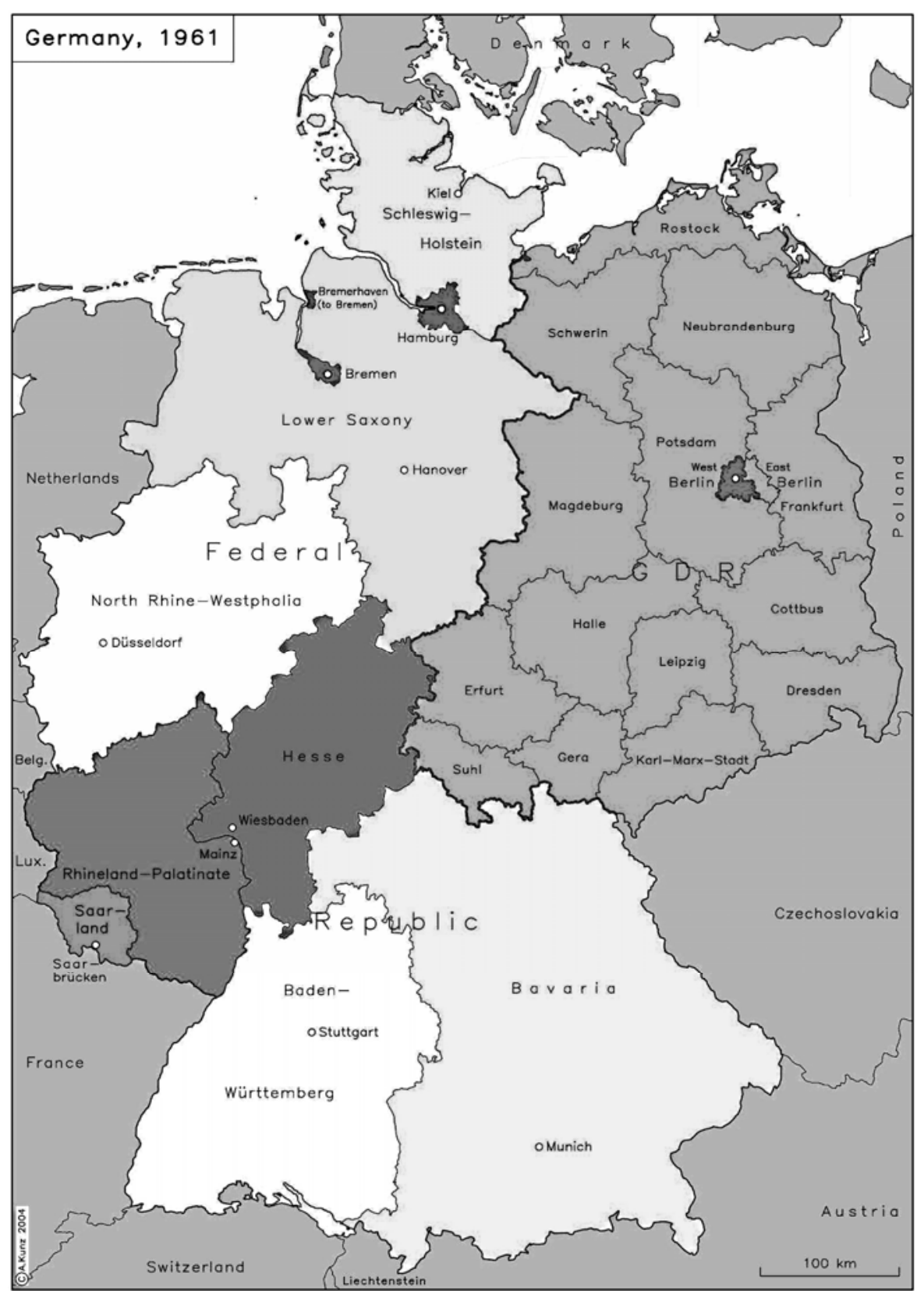

Source: IEG-Maps, Institute of European History, Mainz; available at http://germanhistorydocs.ghi-dc.org/, last accessed on March 6, 2013. 
Figure 3:

Berlin Wall, 1961

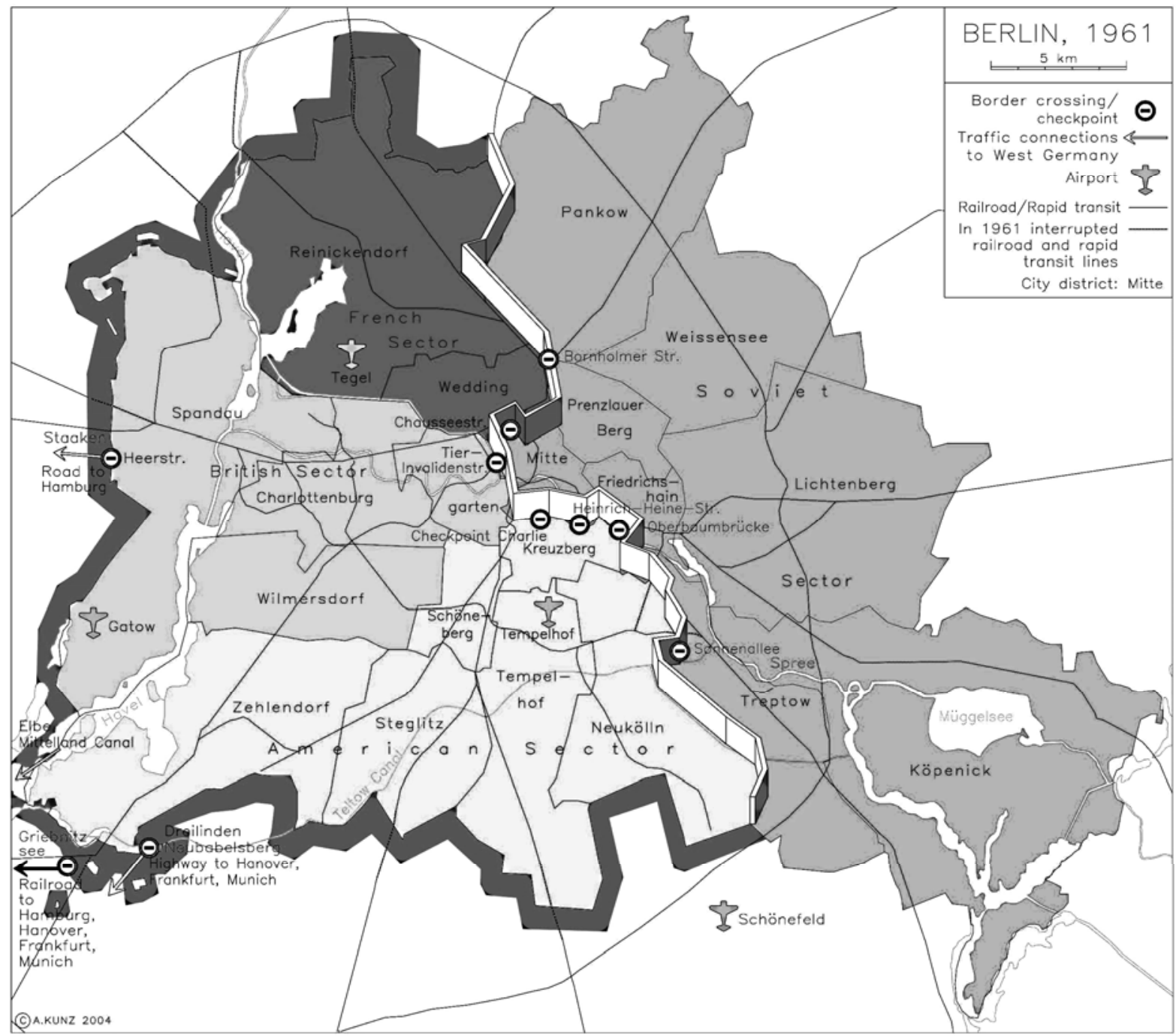

Source: IEG-Maps, Institute of European History, Mainz; available at http://germanhistorydocs.ghi-dc.org/, last accessed on March 6, 2013. 
Figure 4:

Population Development of Berlin: 1816-2010

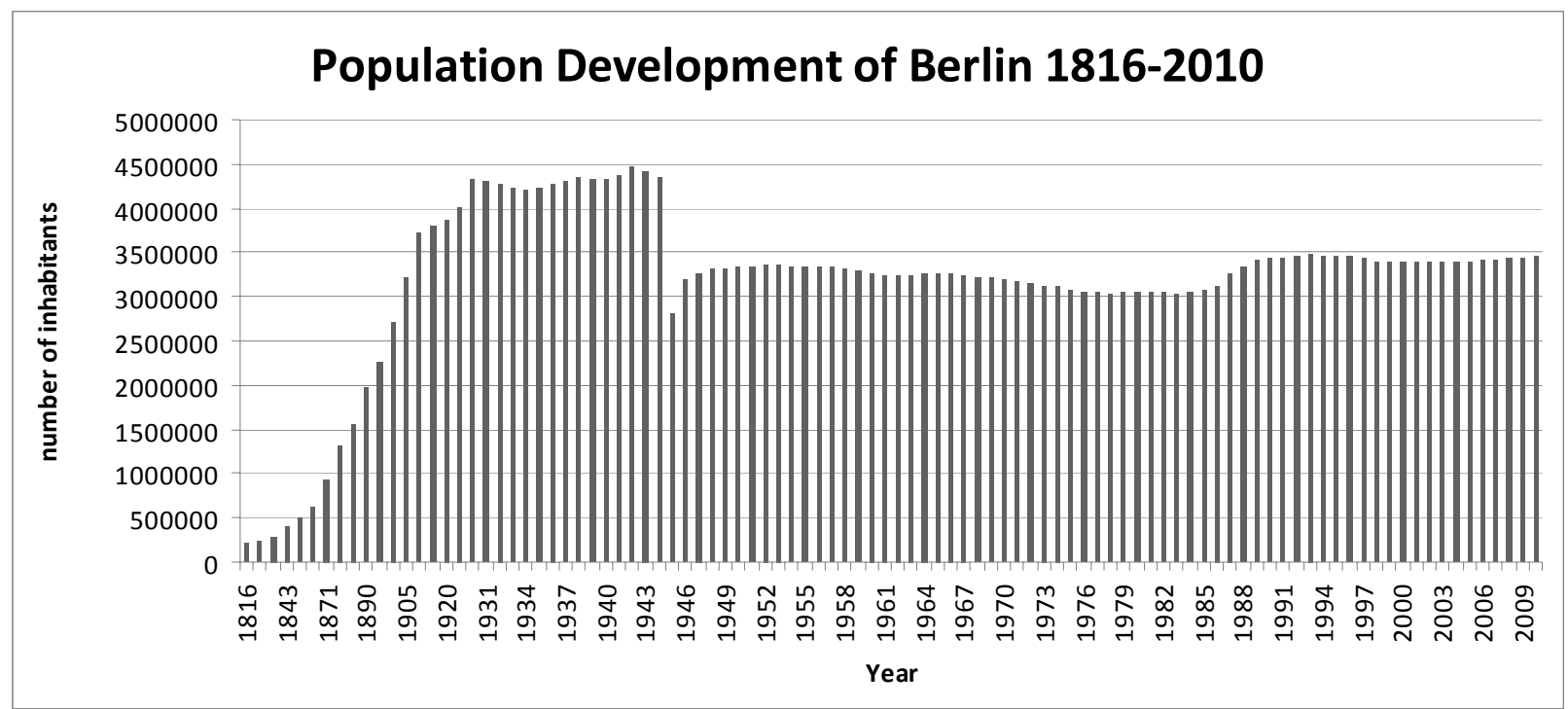

Source: Statistisches Jahrbuch Berlin 2011, Statistik Berlin Brandenburg, Seiten 32-33, available at: http://www.statistik-berlin-brandenburg.de/produkte/jahrbuch/jb2011/JB 2011 BE.pdf, last accessed on March 6, 2013; own illustration. 
Table 1:

Balancing Properties between Respondents Socialized in pre-1989 East vs. West Berlin

\begin{tabular}{l|ccc}
\hline \hline & $\begin{array}{c}\text { East } \\
\text { Berliner }\end{array}$ & $\begin{array}{c}\text { West } \\
\text { Berliner }\end{array}$ & $\begin{array}{c}\text { Normalized } \\
\text { Difference }\end{array}$ \\
Currently living in East Berlin (0=West Berlin) & 0.8625 & 0.0818 & \\
ExAthlete & 0.2275 & 0.2237 & 0.0122 \\
Age & 44.91 & 41.29 & 0.1706 \\
female & 0.5559 & 0.6022 & 0.0686 \\
single & 0.3087 & 0.3557 & 0.0593 \\
fulltime & 0.3858 & 0.4756 & 0.1266 \\
homeowner & 0.2138 & 0.1697 & 0.0830 \\
university degree & 0.3909 & 0.4375 & 0.0688 \\
\# household members & 2.249 & 2.198 & 0.0385 \\
\# household member under 16 & 0.3416 & 0.3742 & 0.0333 \\
Annual household income (10 categories) & 4.813 & 4.502 & 0.0764 \\
& & & \\
\hline $\boldsymbol{N}$ & $\mathbf{1 , 7 5 8}$ & $\mathbf{2 , 1 2 8}$ & \\
\hline
\end{tabular}

Source: own data collection in form of a combined telephone and online survey among Berlin residents between August 9 and September 30, 2011. The last column shows the normalized difference which has been calculated according to $\Delta s=\left(\overline{s_{1}}-\overline{s_{0}}\right) / \sqrt{\sigma_{1}^{2}+\sigma_{0}^{2}}$ with $\overline{s_{1}}$ and $\overline{s_{0}}$ denoting average covariate values for East and West Berliners, respectively. $\sigma$ stands for the variance. As a rule of thumb, normalized differences exceeding 0.25 indicate non-balanced observables that might lead to sensitive results (Imbens and Wooldridge, 2009). 
Table 2:

Model A: $\quad$ The Impact of State Socialization vs. Individual Characteristics on Attitudes and Believes About Doping in Professional Sports: Socialized in East vs. West Berlin before 1989, people over 40

\begin{tabular}{|c|c|c|c|c|c|c|c|c|c|}
\hline & & \multicolumn{2}{|c|}{$\begin{array}{l}\text { Doping is normal in } \\
\text { professional sports }\end{array}$} & \multicolumn{2}{|c|}{$\begin{array}{c}\text { State should heavily sanction } \\
\text { doping offenders }\end{array}$} & \multicolumn{2}{|c|}{$\begin{array}{l}\text { Doping is a structural } \\
\text { issue; athletes are victims }\end{array}$} & \multicolumn{2}{|c|}{$\begin{array}{l}\text { Athletes can be successful } \\
\text { w/o doping }\end{array}$} \\
\hline & & $(1)$ & (2) & (3) & $(4)$ & (5) & (6) & (7) & $(8)$ \\
\hline (A) & EastBerlin* ExAthlete & $\begin{array}{l}0.0736 \\
(0.0512)\end{array}$ & $\begin{array}{l}0.0836 * \\
(0.0513)\end{array}$ & $\begin{array}{l}0.0388 \\
(0.0499)\end{array}$ & $\begin{array}{l}0.0433 \\
(0.0498)\end{array}$ & $\begin{array}{l}-0.0705 \\
(0.0518)\end{array}$ & $\begin{array}{l}-0.0692 \\
(0.0516)\end{array}$ & $\begin{array}{l}0.0426 \\
(0.0488)\end{array}$ & $\begin{array}{l}0.0444 \\
(0.0489)\end{array}$ \\
\hline (B) & Socialized in East Berlin & $\begin{array}{l}-0.0214 \\
(0.0238)\end{array}$ & $\begin{array}{l}-0.0205 \\
(0.0239)\end{array}$ & $\begin{array}{l}0.0000 \\
(0.0229)\end{array}$ & $\begin{array}{l}-0.0009 \\
(0.0232)\end{array}$ & $\begin{array}{l}0.0349 \\
(0.0247)\end{array}$ & $\begin{array}{l}0.0418^{*} \\
(0.0248)\end{array}$ & $\begin{array}{l}-0.0028 \\
(0.0219)\end{array}$ & $\begin{array}{l}-0.0019 \\
(0.0222)\end{array}$ \\
\hline (C) & ExAthlete & $\begin{array}{l}0.0409 \\
(0.0324)\end{array}$ & $\begin{array}{l}0.0153 \\
(0.0325)\end{array}$ & $\begin{array}{l}0.0565 * \\
(0.0314)\end{array}$ & $\begin{array}{l}0.0462^{*} \\
(0.0315)\end{array}$ & $\begin{array}{l}0.0569 * \\
(0.0329)\end{array}$ & $\begin{array}{l}0.0640 * \\
(0.0332)\end{array}$ & $\begin{array}{l}0.0621 * * \\
(0.0307)\end{array}$ & $\begin{array}{l}0.0638 * * \\
(0.0311)\end{array}$ \\
\hline \multicolumn{10}{|c|}{ Other Covariates } \\
\hline & Demographics & no & yes & no & yes & No & yes & no & Yes \\
\hline & $\begin{array}{l}\text { Education \& labor } \\
\text { market }\end{array}$ & no & yes & no & yes & No & yes & no & Yes \\
\hline & $\mathrm{HH}$-Characteristics & no & yes & no & yes & No & yes & no & Yes \\
\hline & $\mathbf{N}$ & 2,182 & 2,182 & 2,182 & 2,182 & 2,182 & 2,182 & 2,182 & 2,182 \\
\hline
\end{tabular}

Source: own data collection in form of a combined telephone and online survey among Berlin residents between August 9 and September 30, 2011. * $p<0.1$, ${ }^{* *} p<0.05, * * * p<0.01$; standard errors are in parentheses. Individual-level clustering does not matter here since the models are based on cross-sectional survey data, which were collected by means of a telephone survey among Berlin residents from August 18-September 30, 2011. Each column stands for one OLS regression model. Treatment status is established based on the pre-1989 East vs. West Berlin residency status and excludes post 1989 migration to Berlin. In columns (1) and (2), the dependent variable is a dummy that is one if respondents agreed with the following statement: "Doping always existed, will always exist, and is an inevitable component of professional sports." In columns (3) and (4), the dependent variable is a dummy that is one if respondents agreed with the following statement: "The state should do everything to prevent doping and sanction doping offenders heavily." In columns (5) and (6), the dependent variable is a dummy that is one if respondents agreed with the following statement: "It is the system of professional sports that has to be blamed for the reoccurring doping cases. The athletes themselves are the victims." In columns (7) and (8), the dependent variable is a dummy that is one if respondents agreed with the following statement: "Who really wants to, can be successful in professional sports without doping." 
Table 3:

Model B: $\quad$ The Impact of State Socialization vs. Individual Characteristics on Doping Attitudes: Socialized in East vs. West Berlin before 1989, flexible Specification

\begin{tabular}{|c|c|c|c|c|c|}
\hline & & $\begin{array}{c}\text { Doping is normal } \\
\text { in professional } \\
\text { sports }\end{array}$ & $\begin{array}{c}\text { State should } \\
\text { heavily sanction } \\
\text { doping offenders }\end{array}$ & $\begin{array}{c}\text { Doping is a } \\
\text { structural issue; } \\
\text { athletes are } \\
\text { victims }\end{array}$ & $\begin{array}{c}\text { Athletes can } \\
\text { be successful } \\
\text { w/o doping }\end{array}$ \\
\hline (A) & $\begin{array}{l}\text { EastBerlin* ExAthlete } \\
\text { *Age }\end{array}$ & $\begin{array}{l}0.0004 \\
(0.0026)\end{array}$ & $\begin{array}{l}0.0048 * * \\
(0.0024)\end{array}$ & $\begin{array}{l}-0.0011 \\
(0.0025)\end{array}$ & $\begin{array}{l}0.0047^{*} \\
(0.0026)\end{array}$ \\
\hline (B) & EastBerlin *Age & $\begin{array}{l}-0.0019 * \\
(0.0012)\end{array}$ & $\begin{array}{l}0.0011 \\
(0.0011)\end{array}$ & $\begin{array}{l}0.0007 \\
(0.0012)\end{array}$ & $\begin{array}{l}0.0002 \\
(0.0011)\end{array}$ \\
\hline (C) & EastBerlin* ExAthlete & $\begin{array}{l}0.0359 \\
(0.1161)\end{array}$ & $\begin{array}{c}-0.1939 * \\
(0.1093)\end{array}$ & $\begin{array}{l}0.0081 \\
(0.1139)\end{array}$ & $\begin{array}{l}-0.219 * \\
(0.1152)\end{array}$ \\
\hline (D) & ExAthlete *Age & $\begin{array}{l}0.0031^{*} \\
(0.0017)\end{array}$ & $\begin{array}{l}-0.0015 \\
(0.0016)\end{array}$ & $\begin{array}{l}0.0009 \\
(0.0017)\end{array}$ & $\begin{array}{l}-0.0029 * \\
(0.0017)\end{array}$ \\
\hline (E) & Socialized in East Berlin & $\begin{array}{l}0.0894 * \\
(0.0548)\end{array}$ & $\begin{array}{l}-0.0605 \\
(0.0508)\end{array}$ & $\begin{array}{l}-0.0136 \\
(0.0549)\end{array}$ & $\begin{array}{l}-0.0227 \\
(0.0516)\end{array}$ \\
\hline (F) & ExAthlete & $\begin{array}{l}-0.1378^{*} \\
(0.0791)\end{array}$ & $\begin{array}{l}0.1095 \\
(0.0774)\end{array}$ & $\begin{array}{l}0.0015 \\
(0.0786)\end{array}$ & $\begin{array}{l}0.2423 * * * \\
(0.0796)\end{array}$ \\
\hline (G) & Age & $\begin{array}{l}-0.0027^{* * *} \\
(0.0009)\end{array}$ & $\begin{array}{l}0.0006 \\
(0.0008)\end{array}$ & $\begin{array}{l}0.0027^{* * *} \\
(0.0009)\end{array}$ & $\begin{array}{l}-0.0003 \\
(0.0008)\end{array}$ \\
\hline \multicolumn{6}{|c|}{ Other Covariates } \\
\hline & $\begin{array}{l}\text { Demographics } \\
\text { Education \& labor } \\
\text { market } \\
\text { HH-Characteristics }\end{array}$ & $\begin{array}{l}\text { yes } \\
\text { yes } \\
\text { yes }\end{array}$ & $\begin{array}{l}\text { Yes } \\
\text { Yes } \\
\text { Yes }\end{array}$ & $\begin{array}{l}\text { Yes } \\
\text { Yes } \\
\text { Yes }\end{array}$ & $\begin{array}{l}\text { yes } \\
\text { yes } \\
\text { yes }\end{array}$ \\
\hline & $\mathbf{N}$ & 3,913 & 3,913 & 3,913 & 3,913 \\
\hline
\end{tabular}

Source: own data collection in form of a combined telephone and online survey among Berlin residents between August 9 and September 30, 2011. ${ }^{*} p<0.1,{ }^{* *} p<0.05, * * * p<0.01$; standard errors are in parentheses. Individual-level clustering does not matter here since the models are based on cross-sectional survey data, which were collected by means of a telephone survey among Berlin residents from August 18-September 30, 2011. Treatment status is established based on the pre-1989 East vs. West Berlin residency status and excludes post 1989 migration to Berlin. Each column stands for one OLS regression model. In columns (1) and (2), the dependent variable is a dummy that is one if respondents agreed with the following statement: "Doping always existed, will always exist, and is an inevitable component of professional sports." In columns (3) and (4), the dependent variable is a dummy that is one if respondents agreed with the following statement: "The state should do everything to prevent doping and sanction doping offenders heavily." In columns (5) and (6), the dependent variable is a dummy that is one if respondents agreed with the following statement: "It is the system of professional sports that has to be blamed for the reoccurring doping cases. The athletes themselves are the victims." In columns (7) and (8), the dependent variable is a dummy that is one if respondents agreed with the following statement: "Who really wants to, can be successful in professional sports without doping." 
Table 4:

Model C: $\quad$ The Impact of State Socialization vs. Individual Characteristics on Doping Attitudes: Robustness Check Including post-1989 Migration to Berlin, Flexible Specification

\begin{tabular}{|c|c|c|c|c|c|}
\hline & & $\begin{array}{c}\text { Doping is } \\
\text { normal in } \\
\text { professional } \\
\text { sports } \\
\end{array}$ & $\begin{array}{c}\text { State should } \\
\text { heavily sanction } \\
\text { doping offenders }\end{array}$ & $\begin{array}{c}\text { Doping is a } \\
\text { structural issue; } \\
\text { athletes are } \\
\text { victims }\end{array}$ & $\begin{array}{c}\text { Athletes can } \\
\text { be successful } \\
\text { w/o doping }\end{array}$ \\
\hline \multirow[t]{2}{*}{ (A) } & EastGermany* ExAthlete*Age & 0.0013 & $0.0047^{* *}$ & -0.0021 & $0.0038^{*}$ \\
\hline & & $(0.0022)$ & $(0.0021)$ & $(0.0022)$ & $(0.0022)$ \\
\hline \multirow[t]{2}{*}{ (B) } & EastGermany *Age & $-0.0019 * *$ & 0.0002 & 0.0012 & -0.0004 \\
\hline & & $(0.0009)$ & (0.0009) & $(0.001)$ & (0.0009) \\
\hline \multirow[t]{2}{*}{ (C) } & EastGermany* ExAthlete & 0.0148 & $-0.2015^{* *}$ & 0.0708 & $-0.2069 * *$ \\
\hline & & (0.0963) & $(0.0915)$ & $(0.0958)$ & (0.0953) \\
\hline \multirow[t]{2}{*}{ (D) } & ExAthlete*Age & $0.0028 *$ & -0.0021 & 0.0017 & -0.0019 \\
\hline & & $(0.0015)$ & $(0.0015)$ & $(0.0015)$ & $(0.0015)$ \\
\hline \multirow[t]{2}{*}{$(E)$} & Socialized in East Germany & $0.0955^{* *}$ & -0.0192 & -0.0416 & 0.0248 \\
\hline & & $(0.0448)$ & $(0.0415)$ & $(0.0452)$ & $(0.0424)$ \\
\hline \multirow[t]{2}{*}{$(F)$} & ExAthlete & $-0.1181^{*}$ & 0.1402 & -0.0464 & $0.1823 * * *$ \\
\hline & & $(0.0707)$ & $(0.0691)$ & (0.0706) & (0.0708) \\
\hline \multirow[t]{2}{*}{ (G) } & Age & $-0.0022 * * *$ & 0.0009 & $0.0018 * *$ & -0.0001 \\
\hline & & $(0.0008)$ & $(0.0008)$ & $(0.0008)$ & $(0.0008)$ \\
\hline \multicolumn{6}{|c|}{ Other Covariates } \\
\hline & Demographics & yes & yes & Yes & Yes \\
\hline & Education \& labor market & yes & yes & Yes & Yes \\
\hline & $\mathrm{HH}-\mathrm{Characteristics}$ & yes & yes & Yes & Yes \\
\hline & $\mathbf{N}$ & 5,877 & 5,877 & 5,877 & 5,877 \\
\hline
\end{tabular}

Source: own data collection in form of a combined telephone and online survey among Berlin residents between August 9 and September 30, 2011. ${ }^{*} p<0.1,{ }^{* *} p<0.05,{ }^{* * *} p<0.01$; standard errors are in parentheses. Individual-level clustering does not matter here since the models are based on cross-sectional survey data, which were collected by means of a telephone survey among Berlin residents from August 18-September 30, 2011. Each column stands for one OLS regression model. Treatment status is established based on the pre-1989 residency status, but - in contrast to the baseline model - includes current residents of Berlin who were socialized in East and West Germany, but not Berlin. In columns (1) and (2), the dependent variable is a dummy that is one if respondents agreed with the following statement: "Doping always existed, will always exist, and is an inevitable component of professional sports." In columns (3) and (4), the dependent variable is a dummy that is one if respondents agreed with the following statement: "The state should do everything to prevent doping and sanction doping offenders heavily." In columns (5) and (6), the dependent variable is a dummy that is one if respondents agreed with the following statement: "It is the system of professional sports that has to be blamed for the reoccurring doping cases. The athletes themselves are the victims." In columns (7) and (8), the dependent variable is a dummy that is one if respondents agreed with the following statement: "Who really wants to, can be successful in professional sports without doping." 
Table 5:

Model D: $\quad$ The Impact of State Socialization vs. Own Experience on Doping Attitudes: Current East vs. West Berliners: Flexible Specification

\begin{tabular}{|c|c|c|c|c|c|}
\hline & & $\begin{array}{c}\text { Doping is } \\
\text { normal in } \\
\text { professional } \\
\text { sports } \\
\end{array}$ & $\begin{array}{c}\text { State should } \\
\text { heavily sanction } \\
\text { doping } \\
\text { offenders } \\
\end{array}$ & $\begin{array}{c}\text { Doping is a } \\
\text { structural issue; } \\
\text { athletes are } \\
\text { victims }\end{array}$ & $\begin{array}{c}\text { Athletes can } \\
\text { be } \\
\text { successful } \\
\text { w/o doping } \\
\end{array}$ \\
\hline \multirow[t]{2}{*}{ (A) } & EastBerlin_now* ExAthlete*Age & 0.0009 & 0.0018 & -0.0002 & $0.0046 * *$ \\
\hline & & $(0.0023)$ & $(0.0022)$ & (0.0023) & $(0.0023)$ \\
\hline \multirow[t]{2}{*}{ (B) } & EastBerlin_now *Age & -0.0014 & 0.0001 & 0.0012 & 0.0001 \\
\hline & & $(0.001)$ & (0.0009) & $(0.0012)$ & $(0.001)$ \\
\hline \multirow[t]{2}{*}{ (C) } & EastBerlin_now* ExAthlete & 0.0858 & -0.1162 & -0.0186 & $-0.2139 * *$ \\
\hline & & $(0.0997)$ & $(0.0941)$ & (0.0989) & $(0.0988)$ \\
\hline \multirow[t]{2}{*}{ (D) } & ExAthlete*Age & $0.0032 * *$ & -0.0007 & 0.0014 & -0.0019 \\
\hline & & $(0.0015)$ & $(0.0014)$ & $(0.0015)$ & $(0.0015)$ \\
\hline \multirow[t]{2}{*}{ (E) } & Currently living in East Berlin & 0.0662 & -0.0084 & -0.0503 & -0.0024 \\
\hline & & $(0.0461)$ & $(0.0426)$ & $(0.0466)$ & (0.0439) \\
\hline \multirow[t]{2}{*}{$(F)$} & ExAthlete & $-0.1324 * *$ & 0.0943 & -0.0503 & $0.1791 * * *$ \\
\hline & & $(0.0678)$ & (0.0426) & (0.0689) & $(0.0683)$ \\
\hline \multirow[t]{2}{*}{ (G) } & Age & $-0.0027 * * *$ & $0.0014^{*}$ & $0.0016^{* *}$ & -0.0005 \\
\hline & & $(0.0008)$ & $(0.0007)$ & (0.0008) & $(0.0007)$ \\
\hline \multicolumn{6}{|c|}{ Other Covariates } \\
\hline & Demographics & Yes & yes & Yes & Yes \\
\hline & Education \& labor market & Yes & yes & Yes & Yes \\
\hline & $\mathrm{HH}$-Characteristics & Yes & yes & Yes & Yes \\
\hline & $\mathbf{N}$ & 5,275 & 5,275 & 5,275 & 5,275 \\
\hline
\end{tabular}

Source: own data collection in form of a combined telephone and online survey among Berlin residents between August 9 and September 30, 2011. ${ }^{*} p<0.1,{ }^{* *} p<0.05, * * * p<0.01$; standard errors are in parentheses. Individuallevel clustering does not matter here since the models are based on cross-sectional survey data, which were collected by means of a telephone survey among Berlin residents from August 18-September 30, 2011. Each column stands for one OLS regression model. Treatment status is established based on the current residency status (East vs. West Berlin). In columns (1) and (2), the dependent variable is a dummy that is one if respondents agreed with the following statement: "Doping always existed, will always exist, and is an inevitable component of professional sports." In columns (3) and (4), the dependent variable is a dummy that is one if respondents agreed with the following statement: "The state should do everything to prevent doping and sanction doping offenders heavily." In columns (5) and (6), the dependent variable is a dummy that is one if respondents agreed with the following statement: "It is the system of professional sports that has to be blamed for the reoccurring doping cases. The athletes themselves are the victims." In columns (7) and (8), the dependent variable is a dummy that is one if respondents agreed with the following statement: "Who really wants to, can be successful in professional sports without doping." 


\section{Appendix A: Questions on Doping Attitudes \& Variables of Interest}

A. Where did you live before the German Reunification, i.e., before 1989 [if you are born after 1989, please indicate where your mother lived before 1989]?

(a) East Berlin (former GDR)

(b) West Berlin (FRG)

(c) Former GDR (excluding East Berlin)

(d) FRG (excluding West Berlin)

(e) Former Eastern bloc countries

(f) Other

B. What is your personal attitude toward doping? You can choose more than one answer.

(a) Doping has always existed, will always exist, and is an unavoidable part of professional sports.

(b) The state should do everything to ban doping. Doping offenders should be heavily punished.

(c) The system of professional sports itself is to blame for doping. The athletes are only the victims.

(d) Those who really want to can be successful in professional sports without doping.

(e) I don't have any opinion about this topic.

C. Are you currently or were you earlier in your life an athlete in an extramural sports club?

(a) Yes, I currently participate in extramural competitive sports.

(b) Yes, earlier in my life I participated in extramural competitive sports.

(c) No, I never participated in extramural competitive sports. 


\begin{tabular}{|c|c|c|c|c|c|}
\hline & Mean & Std. Dev. & Min. & Max. & Obs. \\
\hline \multicolumn{6}{|l|}{ Dependent variables } \\
\hline Doping is normal in professional sports & 0.3961 & 0.4891 & 0 & 1 & 5,877 \\
\hline State should heavily sanction doping offenders & 0.2887 & 0.4532 & 0 & 1 & 5,877 \\
\hline Doping is a structural issue; athletes are victims & 0.4062 & 0.4912 & 0 & 1 & 5,877 \\
\hline Athletes can be successful w/o doping & 0.2913 & 0.4544 & 0 & 1 & 5,877 \\
\hline \multicolumn{6}{|l|}{ Covariates of main interest } \\
\hline Socialized in East Germany pre-1989 (0=West Germany) & 0.5477 & 0.4978 & 0 & 1 & 5,877 \\
\hline Socialized in East Berlin pre-1989 (0=West Berlin) & 0.4562 & 0.4981 & 0 & 1 & 3,913 \\
\hline Currently living in East Berlin ( $0=$ West Berlin) & 0.4686 & 0.4991 & 0 & 1 & 5,275 \\
\hline ExAthlete & 0.2217 & 0.4154 & 0 & 1 & 5,877 \\
\hline Age & 41.55 & 14.35 & 16 & 90 & 5,877 \\
\hline \multicolumn{6}{|l|}{ Other covariates } \\
\hline female & 0.582 & 0.493 & 0 & 1 & 5,877 \\
\hline single & 0.346 & 0.476 & 0 & 1 & 5,877 \\
\hline fulltime & 0.436 & 0.496 & 0 & 1 & 5,877 \\
\hline homeowner & 0.189 & 0.391 & 0 & 1 & 5,877 \\
\hline university degree & 0.420 & 0.494 & 0 & 1 & 5,877 \\
\hline \# household members & 2.231 & 1.175 & 1 & 20 & 5,877 \\
\hline \# household member under 16 & 0.368 & 0.771 & 0 & 19 & 5,877 \\
\hline Annual household income (10 categories) & 4.655 & 2.897 & 0 & 10 & 5,877 \\
\hline
\end{tabular}

